\title{
Syntaxonomic and nomenclatural novelties in the wetland vegetation of Baikal Siberia (Russian Federation)
}

\author{
Victor Chepinoga (*)
}

\begin{abstract}
Chepinoga, V. Syntaxonomic and nomenclatural novelties in the wetland vegetation of Baikal Siberia (Russian Federation). Lazaroa 35: 169-179 (2014).

This paper presents some results of research into vegetation diversity in water bodies and streams in Baikal Siberia, a region in southeast Siberia. The article contains the original diagnoses of five new associations (Callitricho palustris-Subularietum aquaticae, Lemno turioniferae-Thacletum natantis, Ceratophyllo demersi-Eleocharitetum mamillatae, Cariceum pseudocuraicae, Scirpetum orientalis), the typification of one existing association name (Glycerietum spiculosae), and the correction of another name: Tephroseridetum palustris Mirkin \& al. 1985.
\end{abstract}

Keywords: Baikal Siberia, Bidentetea tripartitae, Eastern Siberia, Littorelletea uniflorae, new syntaxa, PhragmitoMagnocaricetea, Russian Federation, wetland vegetation.

Resumen: Chepinoga, V. Novedades sintaxonómicas y nomenclaturales sobre la vegetación de humedales de Baikal (Siberia, Rusia). Lazaroa 35: 169-179 (2014).

Se presentan en este trabajo los resultados de la investigación realizada en los arroyos y charcas de Baikal, una región del sureste de Siberia (Rusia). El articulo contiene las diagnosis originales de cinco asociaciones nuevas: Callitricho palustris-Subularietum aquaticae, Lemno turioniferae-Thacletum natantis, Ceratophyllo demersi-Eleocharitetum mamillatae, Caricetum pseudocuraicae y Scirpetum orientalis; la tipificación del nombre de una asociación ya existente: Glycerietum spiculosae; y la corrección de Tephroseridetum palustris Mirkin \& al. 1985.

Palabras clave: Baikal, Bidentetea tripartitae, este de Siberia, Littorelletea uniflorae, nuevos sintaxones, PhragmitoMagnocaricetea, Federación rusa, vegetación acuática.

\section{INTRODUCTION}

Baikal Siberia is a region located in the eastern part of southern Siberia. The region covers an area of $1550700 \mathrm{~km}^{2}$ and consists of three political units of the Russian Federation: Irkutsk Oblast', Republic of Buryatia and Zabaikalskii Krai (formerly the Chita Oblast') (PeschKova, 1985; ChePINOGA, 2009). Baikal Siberia is well-known because of its wetlands but until recently the diversity of aquatic and wetland vegetation was poorly studied. The recent investigations of flora and vegetation of water bodies and streams in the Baikal Siberia allowed to close this gap (CHEPINOGA, 2013). The vegetation survey of the region (CHEPINOGA, 2013) revealed 105 associations and 12 variants classified into 19 alliances, 11 orders and 5 classes (Lemnetea, Potametea, Littorelletea uniflorae, Phragmito-Magnocaricetea, Bidentetea tripartitae). The classifications of the Lemnetea and the Potamogetonetea were published earlier (CHEPINOGA \& RosBAKH, 2012; CHEPINOGA \& al., 2013). In this paper we present diagnoses of new syntaxa and typifications of existing names of syntaxa of the Littorelletea uniflorae, Phragmito-Magnocaricetea, and Bidentetea tripartitae from the Baikal Siberia.

* Laboratory of Physical Geography \& Biogeography. The V.B. Sochava Institute of Geography SB RAS. Ulan-Batorskaya Str. 1. 664033 Irkutsk, Russia \& Department of Botany. Irkutsk State University. K. Marks Str. 1. 664003 Irkutsk, Russia. Email:Victor.Chepinoga@gmail.com. 


\section{MATERIAL AND METHODS}

During the period from 2002-2010 we studied aquatic and wetland vegetation of the Baikal Siberia. The studied sites were generally arranged along a NW-SSE transect across the region, crossing river plains and valley basins at altitudes of 450-800 $\mathrm{m}$ above sea level. The collected data (more than 2400 relevés), comprise communities of all available types of water bodies, streams, and isolated wetlands. Substantial assistance in the collection of material was provided by Russian (M. Ineshina, S. Rosbakh, A. Verkhozina) and German (A. Hof, Ch. Stumpf-Therre, B. Voges) students and postgraduate students. In addition to the original data we used 345 relevés published earlier from the area (KonOvalov, 1930; SAVICH, 1967; ChytrÝ \& al., 1993, 1995; KAPLAN, 1995; ANENKHONOV, 2003). The complete set of 2,806 relevés was registered in the Global Index of Vegetation-Plot Databases (GIVD) as "Wetland Vegetation Database of Baikal Siberia" (WETBS; ID AS-RU-001; ChEPINOGA, 2012).

The vegetation classification was performed following Braun-Blanquet's phytosociological approach (WESTHOFF \& VAN DER MAAREL, 1973, 1978; DIERSCHKE, 1994). In the classification we follow the method which is similar to that employed by ŠUMBEROVÁ (2011) and ŠUMBEROVÁ \& al. (2011a, 2011b) for the classification of aquatic vegetation of the Czech Republic.

Data processing and classification were carried out using the software package IBIS (Integrated Botanical Information System), the vegetation database management software (ZvEREv, 2007). The software package JUICE (TICHÝ, 2002) was used for determination of diagnostic, constant and dominant species. Diagnostic species include differential and character (or indicator) species determined by measuring statistical fidelity using the phi coefficient (CHYTRÝ \& al., 2002). Species with phi coefficient above 0.25 were considered diagnostic for a particular association while species with a phi coefficient above 0.50 were considered highly diagnostic. The latter are underlined in the vegetation description, below. Statistical significance of association fidelity was calculated using Fisher's exact test (CHYTRÝ \& al., 2002) at a level of significance $\mathrm{P}<0.001$. Constant or highly constant species were those with a frequency over $40 \%$ or $80 \%$, respectively. Dominant species and highly dominant species were those that occurred with a cover value exceeding $25 \%$ in at least $15 \%$ and $30 \%$ of relevés, respectively. Highly constant and highly dominant species are underlined in the vegetation description, below.

The nomenclature of taxa follows CHEPINOGA \& al. (2008) for vascular plants, Ignatov \& al. (2006) for mosses, and KONSTANTINOVA \& BAKALIN (2009) for liverworts. In numerical analyses Lemna minor was treated in the broad sense, i.e. including L. minor s. str. and L. turionifera. The nomenclature of syntaxa follows the rules of the International Code of Phytosociological Nomenclature (ICPN; WEBER \& al., 2000).

\section{RESULTS AND DISCUSSION}

Callitricho palustris-Subularietum aquaticae de Molenaar ex Chepinoga ass. nova hoc loco

(Original form: 'Callitricho-Subularietum aquaticeae ass. nov. prov.' de Molenaar 1976 (ICPN art. $3 b)$

Holotypus: De MolenAAR, 1976: 38, rel. 1, Table 2 (Subularia aquatica 4, Callitriche verna (=C.palutris) 3, Hippuris vulgaris + ).

Syntaxonomic position: Littorelletea uniflorae; Littorelletalia uniflorae; Littorellion uniflorae

Diagnostic species: Subularia aquatica. Constant species: Isoëtes echinospora, Potamogeton

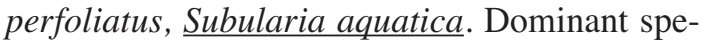
cies: Subularia aquatica

Aquatic communities of oligotrophic lakes with dominance of Subularia aquatica.

Structure. Low cover (25-35\%) and species pure communities with stand size often exceeding $100 \mathrm{~m}^{2}$.

Ecology. Communities of S. aquatica as well as Isoëtes echinospora, occur in oligotrophic lakes. Stands of $S$. aquatica prefer places with silty bottom and depth more than one meter.

S. aquatica s.l. is a mainly boreal circumpolar species. In Northern Eurasia it occurs more often in regions with humid oceanic climate, 
while in Siberia it is extremely rare species. More than half of Siberian populations of the species are known from north of the Baikal Siberia (ChePINOGA \& al., 2008). We have only two original relevés from the Lake Dalneye in western foothills of the Baikalskii Ridge. Communities of $S$. aquatica are also known from lower courses of the Verkhnaya Angara River, Baikalskii Ridge and Frolikha Lake (Azovsky, 1981, 2000).

\section{Lemno turioniferae-Thacletum natantis ass. nova hoc loco}

Holotypus: rel. 6, Table 1.

\begin{tabular}{|c|c|c|c|c|c|c|c|c|c|c|c|c|}
\hline (Ele & $\begin{array}{l}\text { le } 1 \\
\text { cletu } \\
\text { alia } 2\end{array}$ & $\begin{array}{l}\text { ma } \\
\text { iniflo }\end{array}$ & $\begin{array}{l}\text { tant } \\
\text { rae }\end{array}$ & $\begin{array}{l}\text { is ass } \\
\text { Littor }\end{array}$ & $\begin{array}{l}\text { nov } \\
\text { rellet }\end{array}$ & $\begin{array}{l}a \\
e a u\end{array}$ & ifflo & $a e)$ & & & & \\
\hline Area $\left(m^{2}\right)$ & 6 & 25 & 6 & 2 & 4 & 18 & 14 & 4 & 2 & 16 & 2 & 3 \\
\hline Cover $(\%)$ & 70 & 95 & 75 & 100 & 98 & 95 & 85 & 80 & 80 & 90 & 55 & 95 \\
\hline Average depth $(\mathrm{cm})$ & 20 & 25 & 15 & 3 & 15 & 15 & 5 & 20 & 12 & 7 & 10 & 15 \\
\hline Soil char. & si & $\mathrm{c}$ & si & sag & $\mathrm{c}$ & $\mathrm{c}$ & $\mathrm{sc}$ & $\mathrm{sg}$ & si & ss & si & $\mathrm{sc}$ \\
\hline N. of taxa & 2 & 2 & 3 & 3 & 5 & 5 & 5 & 6 & 6 & 8 & 9 & 12 \\
\hline N. relevé & 1 & 2 & 3 & 4 & 5 & 6 & 7 & 8 & 9 & 10 & 11 & 12 \\
\hline Characteristics of Lemno & & & & & & & & & & & & \\
\hline $\begin{array}{l}\text { Thacla natans } \\
\text { Characteristics of Littore }\end{array}$ & 4 & 4 & 4 & 4 & 4 & 4 & 5 & 5 & 5 & 5 & 3 & 4 \\
\hline $\begin{array}{l}\text { Callitriche palustris } \\
\text { Characteristics of Lemne }\end{array}$ & . & . & . & . & $\mathrm{r}$ & + & . & . & 1 & + & . & . \\
\hline Lemna turionifera & . & 3 & $\mathrm{r}$ & . & 3 & 2 & . & . & . & . & + & 2 \\
\hline $\begin{array}{l}\text { Lemna trisulca } \\
\text { Characteristics of Phragr }\end{array}$ & . & . & . & . & . & . & . & . & . & . & $\mathrm{r}$ & + \\
\hline Glyceria triflora & . & . & . & . & 2 & . & 1 & + & + & 2 & . & $\mathrm{r}$ \\
\hline Beckmannia syzigachne & . & . & . & . & . & . & . & . & . & $\mathrm{r}$ & 2 & + \\
\hline Equisetum fluviatile & . & . & . & . & . & . & . & + & 1 & . & . & 2 \\
\hline Eleocharis palustris & . & . & . & . & . & . & . & + & . & + & . & . \\
\hline Eleocharis mamillata & 1 & . & . & . & $\mathrm{r}$ & . & . & . & . & . & . & . \\
\hline Companions & & & & & & & & & & & & \\
\hline Ranunculus sceleratus & . & . & . & $\mathrm{r}$ & . & . & . & . & . & . & $\mathrm{r}$ & $\mathrm{r}$ \\
\hline Agrostis stolonifera & . & . & . & . & . & $\mathrm{r}$ & . & . & . & + & . & $\mathrm{r}$ \\
\hline Persicaria hydropiper & . & . & . & . & . & $\mathrm{r}$ & . & . & . & $\mathrm{r}$ & . & $\mathrm{r}$ \\
\hline Bidens raidatus & . & . & . & . & . & . & $\mathrm{r}$ & . & . & $\mathrm{r}$ & . & \\
\hline
\end{tabular}

Other species: Carex vesicata 2 in 3; Ranunculus radicans 3 in 4; Agrostis gigantea r, Juncus ranarius + in 7; Carex acuta and Hippuris vulgaris + in 8; Sparganium glomeratum + , Ranunculus gmelinii 1 in 9; Alisma plantago-aquatica, Alopecurus aequalis and Riccia rhenana r, Cicuta virosa 1 in 11; Carex rostrata and Typha latifolia + , Spirodela polyrhiza 1 in 12 .

Localities: 1,9: Irkutskaya Oblast', Ziminskii Raion, Osipovskii village, pond in the village, $53^{\circ} 31^{\prime} \mathrm{N} 101^{\circ} 33{ }^{\prime} \mathrm{E}, 09.07 .2005$, V. Chepinoga (05-502a, 05-502c); 2,5,6: Irkutskaya Oblast', Tulunskii Raion, Ikei village, pool on roadside ditch, $54^{\circ} 13 ' \mathrm{~N}$ $100^{\circ} 04^{\prime} \mathrm{E}, 24.07 .2006$, V. Chepinoga (06-630c, 06-630d, 06-630a); 3,7: Zabaikalskii Krai, Uletovskii Raion, in vicinity of Goreka village, the Goreka river near the bridge, 51 ${ }^{\circ} 04^{\prime} \mathrm{N} 111^{\circ} 59^{\prime} \mathrm{E}, 07.08 .2007$, V. Chepinoga (07-734b, 07-734d); 4: Irkutskaya Oblast', Tulunskii Raion, south outskirts of the Perfilovo village, backwater of the Sharagol River (left tributary of the Manut River), $54^{\circ} 24^{\prime} \mathrm{N} 100^{\circ} 26^{\prime} \mathrm{E}, 21.07 .2006$, B. Voges (V06-613d); 8: Irkutskaya Oblast', Ziminskii Raion, Osipovskii village, pond in the village, backwater, $53^{\circ} 31^{\prime} \mathrm{N} 101^{\circ} 33^{\prime} \mathrm{E}, 09.07 .2005$, S. Rosbakh (R05-498d); 10: Irkutskaya Oblast', Tulunskii Raion, $3 \mathrm{~km}$ W of the Uygat, left riverside of the Kirei River, puddle on the road, $54^{\circ} 05^{\prime} \mathrm{N} 100^{\circ} 33^{\prime} \mathrm{E}$, 30.06.2007, V. Chepinoga (07-683a); 11: Irkutskaya Oblast', Cheremkhovskii Raion, Bazhei village, floodplain lakelet, $52^{\circ} 58^{\prime} \mathrm{N} 102^{\circ} 39^{\prime} \mathrm{E}, 02.08 .2006$, V. Chepinoga (06-670c); 12: Irkutskaya Oblast', Tulunskii Raion, Edogon village, pond near the old road, $54^{\circ} 17^{\prime} \mathrm{N} 100^{\circ} 15^{\prime} \mathrm{E}, 22.07 .2006$, V. Chepinoga (06-618a). Holotypus ass. rel. 6.

Abbreviations: d.s.: diagnostic species; Soil char.: c: clay, cg: clayey gravel, g: gravel, sa: sand, sag: sandy gravel, sc: silty clay, sg: silty gravel, si: silt, sp: silty peat, ss: silty sand. 
Table 2

Ceratophyllo demersi-Eleocharitetum mamillatae ass. nova (Eleocharito palustris-Sagittarion sagittifoliae, Phragmitetalia australis, Phragmito-Magnocaricetea)

\begin{tabular}{lcccccccccc}
\hline Area $\left(\mathrm{m}^{2}\right)$ & 8 & 4 & 4 & 30 & 20 & 32 & 16 & 50 & 6 & 4 \\
Cover $(\%)$ & 85 & 75 & 40 & 100 & 50 & 100 & 75 & 100 & 70 & 100 \\
Average depth $(\mathrm{cm})$ & 15 & 10 & 10 & 15 & 30 & 15 & 20 & 15 & 5 & - \\
Soil char. & sa & si & sa & si & - & si & - & sag & si & - \\
N. species & 1 & 2 & 3 & 4 & 4 & 5 & 6 & 6 & 7 & 10 \\
Relevé N. & 1 & 2 & 3 & 4 & 5 & 6 & 7 & 8 & 9 & 10
\end{tabular}

Characteristics of Ceratophyllo-Eleocharitetum mamillatae (d.s.)

Eleocharis mamillata

Characteristics of Phragmito-Magnocaricetea (d.s.)

Typha latifolia

Comarum palustre

Carex rostrata

Characteristics of Lemnetea (d.s.)

Ceratophyllum demersum

Lemna minor

Lemna trisulca

Characteristics of Potametea (d.s.)

Elodea canadensis

Characteristics of Littorelletea uniflorae (d.s.)

Ranunculus gmelinii

Utricularia macrorhiza

\begin{tabular}{|c|c|c|c|c|c|c|c|c|}
\hline 5 & 4 & 3 & 5 & 3 & 5 & 4 & 4 & 4 \\
\hline$\cdot$ & . & $\mathrm{r}$ & . & . & $\mathrm{r}$ & . & . & $\mathrm{r}$ \\
\hline . & . & . & . & . & . & $\mathrm{r}$ & . & . \\
\hline - & . & . & + & . & $\mathrm{r}$ & . & . & . \\
\hline - & . & . & 2 & . & . & · & 3 & . \\
\hline . & . & . & . & 1 & . & + & . & . \\
\hline . & . & . & . & + & . & + & . & . \\
\hline$\cdot$ & . & . & 2 & ${ }^{\circ}$ & 3 & . & 2 & . \\
\hline$\cdot$ & . & . & . & 1 & . & + & . & . \\
\hline & . & . & . & . & . & . & $\mathrm{r}$ & . \\
\hline
\end{tabular}

Other species: Scirpus sylvaticus $\mathrm{r}$ in 2; Potamogeton berchtoldii $\mathrm{r}$ in 3; Drepanocladus aduncus 2 in 6; Alisma plantago-aquatica and Ranunculus reptans + in 7; Potamogeton compressus $\mathrm{r}$ in 8; Equisetum palustre $\mathrm{r}$, Agrostis gigantea and A. stolonifera + , Carex rhynchophysa 1, Potamogeton perfoliatus 2 in 9; Calla palustris, Carex canescens, C. diandra and Menyanthes trifoliata + Hippuris vulgaris 1, Sparganium natans 2 in 10.

Localities: 1,3: Irkutskaya Oblast', Tulunskii Raion, in vicinity of the Ikei village, quarry lake, $054^{\circ} 13^{\prime} \mathrm{N} 100^{\circ} 04^{\prime} \mathrm{E}$, 24.07.2006, S. Rosbakh, (R06-634e, R06-634b); 2: Irkutskaya Oblast', Taishetskii Raion, outskirts of the Yurty village, pond on the Cheremshanka River, $056^{\circ} 02^{\prime} \mathrm{N} 07^{\circ} 37^{\prime} \mathrm{E}, 28.07 .2006$, S. Rosbakh, (R06-651m); 4,6: Irkutskaya Oblast', Ziminskii Raion, outskirts of the Zulumai village, oxbow in floodplain of the Zima River, $053^{\circ} 42^{\prime} \mathrm{N}$ $101^{\circ} 22^{\prime} \mathrm{E}, 12.07 .2005$, V. Chepinoga, (05-515c, 05-515r); 5: Buryatia Republic, Barguzinskii raion, Zabaikalskii National Park, Svyatoi Nos peninsula on the East coast of the Lake Baikal, mires near Elchikha settlement, 05332'55"N 10857'00"E, 01.07.1991, (C93-8.12; CHYTRY \& al., 1993); 7: Buryatia Republic, Barguzinskii raion, Zabaikalskii National Park, Svyatoi Nos peninsula on the East coast of the Lake Baikal, coast of Barmashovye Lakes, 05328'13"N 10900'31"E, 01.07.1991, (C93-8.10; CHYTRY \& al., 1993); 8: Irkutskaya Oblast', Ziminskii Raion, outskirts of the Zulumai village, oxbow in floodplain of the Zima River, $053^{\circ} 42^{\prime} \mathrm{N} 101^{\circ} 22^{\prime} \mathrm{E}, 12.07 .2005$, S. Rosbakh, (R05-516p); 9: Irkutskaya Oblast', Tulunskii Raion, 5 km S of Mugun village, near to the Algatui village, pond Algatuiskii, 054 24'N 100¹5'E, 24.07.2006, V. Chepinoga, (06-637p); 10: Buryatia Republic, Barguzinskii raion, Zabaikalskii National Park, Svyatoi Nos peninsula on the East coast of the Lake Baikal, Samovye Lakes, 05335'30"N 10853'30"E, 01 .06.1991, (C93-8.13, CHYTRY \& al., 1993). Holotypus ass. rel. 4.

For the abbreviations, see Table 1.

Syntaxonomic position: Littorelletea uniflorae; Littorelletalia uniflorae; Eleocharition acicularis

Diagnostic species: Thacla natans. Constant species: Glyceria triflora, Lemna minor s.l. (L. turionierfa), Thacla natans. Dominant species: Lemna minor s.1. (L.turionifera), Thacla natans.
Communities of Thacla natans (=Caltha natans) on shallow waters.

Structure. Small sized stands $\left(2-25 \mathrm{~m}^{2}\right)$ with cover varying from (55)70 to $100 \%$. The single stands were found to contain 2 to 12 species, where generally $T h$. natans is markedly dominant. Other constant species, Lemna minor s.l., 
was recorded in 6 of 12 relevés. The average number of species per relevé is 5.5. Among the 28 species recorded in 12 relevés, 19 species were found only once or twice.

Ecology. Communities of Th. natans occur on wet roadside ditches, in shallow water $(3-25 \mathrm{~cm})$ of floodplain lakes and ponds, rare in small river lentic backwaters. The stands prefer soft bottom composition made of silt or clay, rarely they can be found on silty sand or gravel.

Distribution. Th. natans is a boreal and temperate species with North American and North Asian distribution. The western limit of its main distribution area in Asia lies on the Yenisei River. Single locations are known also from Western Siberia. We did not find any publication referring to this type of vegetation from the Russian territory. In the Baikal Siberia, Th. natans is relatively common species, especially eastwards from the Lake Baikal but the association is rather rare. The Lemno turioniferae-Thacletum natantis was found in the basins of the Iya, Belaya and Ingoda rivers.

Besides the Lemno turioniferae-Thacletum natantis, the Eleocharition acicularis is presented in Baikal Siberia by other four associations, such as the Limosello aquaticae-Eleocharitetum acicularis, Leptodictyo riparii-Ranunculetum gmelinii (incl. Hippuro-Ranunculetum gmelinii Pestrjakov \& Gogoleva 1989 nom. inval.), Subulario-Ranunculetum reptantis, and Lemno-Callitrichetum palustris. The Limosello aquaticae-Eleocharitetum acicularis is a most common in the Baikal Siberia. Other associations are less common although typical for more humid Cisbaikalia (west of the Lake Baikal) than for the arid south of Transbaikalia.

Ceratophyllo demersi-Eleocharitetum mamillatae ass. nova hoc loco

Holotypus: rel. 4, Table 2

Synonyms: Eleocharitetum mamillatae Passarge 1999 [ICPN Art. 5]

Syntaxonomic position: Phragmito-Magnocaricetea; Phragmitetalia australis; Eleocharito palustris-Sagittarion sagittifoliae

Diagnostic species: Eleocharis mamillata. Constant species: Eleocharis mamillata; Dominant species: Eleocharis mamillata
Shallow water communities with dominance of Eleocharis mamillata (H. Lindb.) H. Lindb., s.str. (excl. E. austriaca Hayek, E. ussuriensis Zinserl.).

Structure. Stands consist of 1-10 species and stand size varies from small to middle till $50 \mathrm{~m}^{2}$. In 10 relevés are registered 27 species. All of the accompanying E. mamillata species have low frequency in relevés; 17 species were recorded only once.

Ecology. Communities of E. mamillata are typical for oxbow and quarry lakes and ponds on shallow water till depth $30 \mathrm{~cm}$. The stands occur usually on soft bottom substrate comprised of silt or silty sand.

Distribution. E. mamillata is a boreal and temperate circumpolar species. In Baikal Siberia it grows mainly westwards from the Lake Baikal. The communities of E. mamillata are known from Birjusa, Iya, Oka, and Zalari rivers. Some relevés obtained from CHYTRÝ \& al. (1993) were from Svyatoi Nos Peninsula on the east coast of the Lake Baikal.

Besides E. austriaca and E. ussuriensis, E. mamillata is one of the species belonging to aggregate E. palustris s.l. There are two main options how the communities of these species can be treated syntaxonomically. The first, and the simplest one, is to include them in one association Eleocharitetum palustris Savich 1926 nom. mut. prop. (e.g., ŠUmberovÁ \& al., 2011a) by the reason of morphological and ecological similarity of all species forming E. palustris agg. Other option is to try to treat stands of different species from the aggregate as unranked communities (e.g., E. mamillata community - CHYTRÝ \& al., 1993), or as separate associations. The communities of E. mamillata are known from Europe under invalid name Eleocharitetum mamillatae Passarge 1999, because original diagnosis doesn't contain any relevé and no one earlier published relevé is indicated as a nomenclatural type (PASSARGE, 1999). By reason that distribution areas of E. mamillata s.str. and E. austriaca are overlapping in Europe and often these two closely related species are mixing (GERGOR, 2003), we consider reasonable to describe the association with dominance of $E$. mamillata s.str. from the Baikal Siberia, where $E$. 
austriaca is missing that prevents mixing of these two community types. It should be noted that the association Eleocharitetum austriacae Kipriyanova \& Lashchinsky 2000 is already described from Western Siberia (KIPRIANOVA \& LASHCHINSKY, 2000).

Data from Baikal Siberia shows the pronounced difference in ecology of Ceratophyllo demersi-Eleocharitetum mamillatae and Eleocharitetum palustris (Figure 1). This fact determined the final decision to accept stands of E. mamillata as a separate association.

\section{Scirpetum orientalis ass. nova hoc loco}

Holotypus: rel. 6, Table 3

Syntaxonomic position: Phragmito-Magnocaricetea; Magnocaricetalia; Magnocaricion elatae

Diagnostic species: $\underline{\text { Carex heterolepis, Juncus }}$ filiformis, Poa pratensis, Scirpus orientalis, Stellaria media. Constant species: Cicuta virosa, Scirpus orientalis. Dominant species: Scirpus orientalis

Wetland communities with dominance of Scirpus orientalis.

Structure. Medium-sized communities up to 50 $\mathrm{m}^{2}$, consisting of five to 18 species. The cover is usually high (average value $88 \%$ ). Beside $S$. orientalis, as a constant species was determined only Cicuta virosa. Two-thirds of species registered in relevés were found on sample plots only once.

Ecology. Stands grow on clayey, sandy or stony substrata along wet river banks and backwaters.

Distribution. S. orientalis is a temperate and meridional species distributed in Siberia, the Far East, Mongolia and Nord-Eastern China. Geographically, S. orientalis is an Asian vicariant species of the European and West Siberian S. sylvaticus. While the species $S$. orientalis is comparatively well distributed in Baikal Siberia, the association is rather rare. The communities are recorded in Cisbaikalia (Iya, Oka, Belaya and Kitoi river basins) and in Transbaikalia (Chikoi and Ingoda river basins).

Ecologically, the Scirpetum orientalis as well as some other associations (e.g. Caricetum vesicatae, etc.) of the Magnocaricion elatae are transitional between wetland (Phragmito-Magnocaricetea) and wet meadow (Molinio-Arrhenatheretea and Calamagrostietea langsdorffii) vegetation.

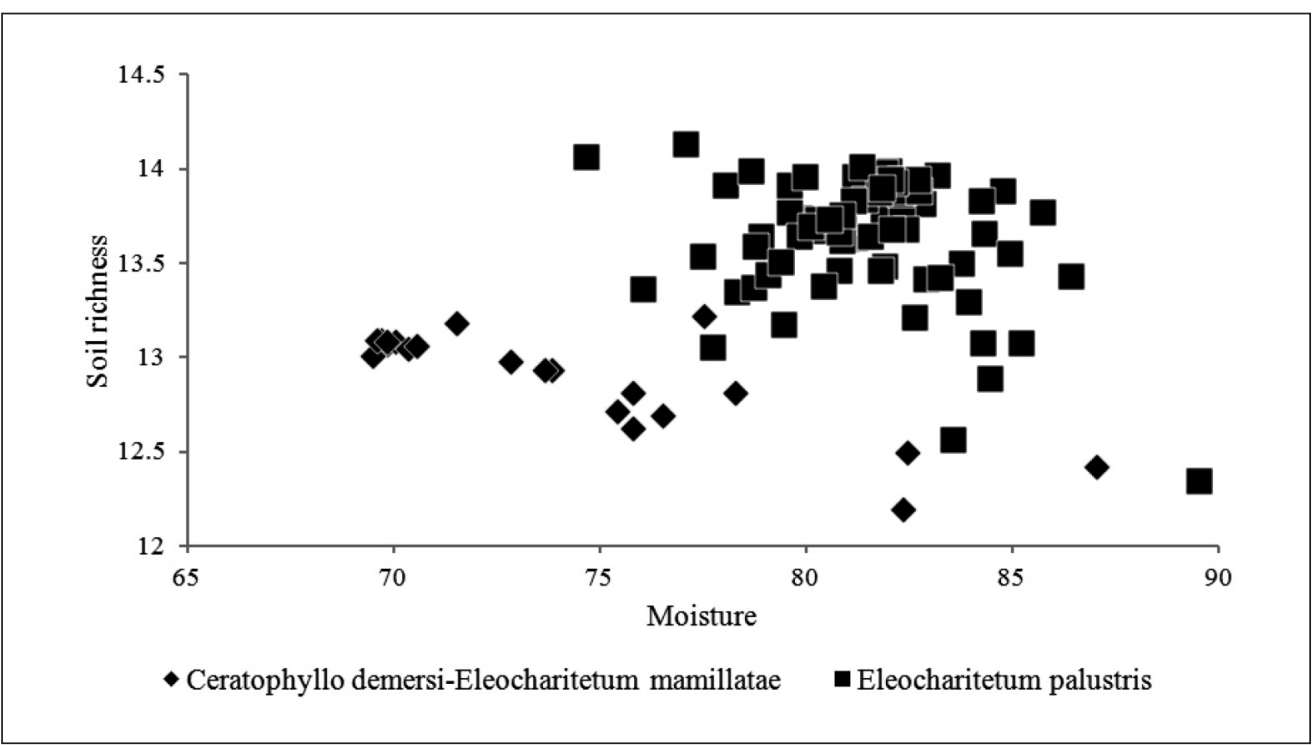

Figure 1. - Ordination of the Ceratophyllo demersi-Eleocharitetum mamillatae and the Eleocharitetum palustris using Ramensky indicator values. For ordination the optimum values for South Siberian plant species after A. Koroljuk (2006) are used. The dimension of the soil richness scale is 30 grades and the moisture scale is 120 grades. 
Table 3

Scirpetum orientalis ass. nova

(Magnocaricion elatae, Magnocaricetalia, Phragmito-Magnocaricetea)

\begin{tabular}{lccccccccc}
\hline Area $\left(\mathrm{m}^{2}\right)$ & 20 & 6 & 30 & 6 & 50 & 50 & 20 & 50 & 40 \\
Cover shrub layer (\%) &. &. &. &. &. &. & 3 &. &. \\
Cover herb layer (\%) & 95 & 95 & 80 & 60 & 100 & 98 & 97 & 85 & 85 \\
Cover moss layer (\%) &. & 35 &. &. &. &. &. & 2 &. \\
Average depth (cm) &. & 0 & 0 &. & 0 &. & 0 & 0 & 0 \\
Soil char. & c & sa & cg & c & g & c & sa & ss & g \\
N. species & 5 & 9 & 9 & 11 & 12 & 12 & 17 & 17 & 18 \\
Relevé N. & 1 & 2 & 3 & 4 & 5 & 6 & 7 & 8 & 9 \\
\hline
\end{tabular}

Characteristics of Scirpetum orientalis (d.s.)

Scirpus orientalis

Carex heterolepis

Juncus filiformis

Poa pratensis

Stellaria media

Characteristics of Phragmito-Magnocaricetea (d.s.)

Carex acuta

Carex rhynchophysa

Carex rostrata

Carex vesicata

Eleocharis palustris

Equisetum fluviatile

Glyceria triflora

Other species

Agrostis gigantea

Alopecurus pratensis

Beckmannia syzigachne

Cicuta virosa

Equisetum arvense

Glyceria spiculosa

Myosotis caespitosa

Potentilla anserina

Ranunculus repens

Salix rorida, b

Sium suave

Vicia cracca

\begin{tabular}{|c|c|c|c|c|c|c|c|c|}
\hline 4 & 4 & 3 & 3 & 5 & 4 & 3 & 4 & 4 \\
\hline . & + & . & 1 & . & . & 1 & . & . \\
\hline . & . & - & 2 & . & 2 & . & + & . \\
\hline • & . & $\cdot$ & - & $\mathrm{r}$ & . & + & • & $\mathrm{r}$ \\
\hline+ & . & . & . & . & + & . & . & . \\
\hline . & . & $\mathrm{r}$ & . & . & . & . & 1 & 1 \\
\hline . & 2 & 1 & . & . & . & . & · & • \\
\hline 2 & . & . & . & . & 2 & . & . & . \\
\hline . & . & 2 & . & 2 & . & 1 & . & . \\
\hline . & . & 1 & . & . & + & 2 & . & . \\
\hline . & 2 & . & - & . & . & . & + & . \\
\hline . & $\cdot$ & 2 & • & $\mathrm{r}$ & . & . & 1 & . \\
\hline · & $\cdot$ & $\cdot$ & - & - & - & 1 & . & $\mathrm{r}$ \\
\hline . & . & . & - & $\mathrm{r}$ & . & - & . & + \\
\hline . & + & $\mathrm{r}$ & . & - & - & - & . & . \\
\hline+ & $\cdot$ & . & . & $\mathrm{r}$ & + & . & . & $\mathrm{r}$ \\
\hline . & . & $\mathrm{r}$ & . & . & . & . & . & 2 \\
\hline 2 & . & · & - & . & 2 & . & . & . \\
\hline$\cdot$ & $\cdot$ & · & - & · & 1 & . & $r$ & . \\
\hline$\cdot$ & $\cdot$ & . & - & 1 & . & . & . & 2 \\
\hline$\cdot$ & $\cdot$ & . & - & . & 1 & . & 2 & + \\
\hline$\cdot$ & $\cdot$ & - & - & $\cdot$ & - & - & $r$ & $\mathrm{r}$ \\
\hline . & $\cdot$ & - & $\cdot$ & $\mathrm{r}$ & $\cdot$ & - & & $\mathrm{r}$ \\
\hline$\cdot$ & . & - & $\mathrm{r}$ & . & . & . & & $\mathrm{r}$ \\
\hline
\end{tabular}

Other species: Rorippa palustris r, Salix rhamnifolia (b) and Equisetum palustre + , Poa palustris 1 in 2 ; Pedicularis karoi $\mathrm{r}$ in 3; Amoria repens, Cirsium setosum, Larix sibirica (c) and Thacla natans r, Ranunculus gmelinii and Salix sp. (c) +, Truellum sieboldii 2 in 4; Lithospermum officinale and Salix miyabeana (c) r, Carex dichroa + , Agrostis stolonifera 2in 5; Comarum palustre and Scutellaria galericulata r, Persicaria hydropiper 1 in 6; Hippochaëte hyemalis and Rumex protractus r, Carex curaica, Carex serotina and Phragmites australis,+ Calamagrostis pseudophragmites, Juncus fischerianus, Juncus arcticus and Salix taraikensis (b) 1, Deschampsia cespitosa 2, H. variegata 3 in 7; Calamagrostis langsdorffii, Callitriche palustris and Caltha palustris, Myosotis palustris, Salix gmelinii (b), Salix gmelinii (c) r, Equisetum arvense var. decumbens and Salix rorida (c) +, Brachythecium mildeanum (d) 1 in 8; Elymus sibiricus, Mentha canadensis, Persicaria lapathifolia, Salix miyabeana (b) r, Triglochin palustre r, Bidens radiatus + in 9.

Localities: 1,6: Irkutsk Oblast', Zalarinskii Raion, Khor-Tagna village, wet bank of the Tagna River within the set-

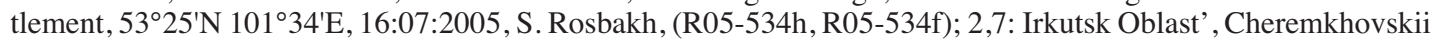
Raion, $15 \mathrm{~km}$ SW of Golumet' village, oxobow in floodplain of the Bolshaya Belaya river, 051 ${ }^{\circ} 59^{\prime} 59^{\prime \prime} \mathrm{N}$ 102 ${ }^{\circ} 14^{\prime} 00 " E, 19: 07: 2002$, V. Chepinoga (02-128c, 03-129); 3: Zabaikalskii Krai, Uletovskii Raion, 2 km S of the Shelokhan village, left bank of the Ingoda River, $051^{\circ} 00^{\prime} \mathrm{N} 111^{\circ} 56^{\prime} \mathrm{E}, 07: 08: 2007$, V. Chepinoga, (07-730f); 4: Irkutsk Oblast', Usolskii Raion, $7 \mathrm{~km}$ upstream the Bolshoi Zadoi River from Taliany village, islet on the river, $052^{\circ} 09^{\prime} \mathrm{N} 103^{\circ} 09^{\prime} \mathrm{E}, 09: 08: 2002$, V. Chepinoga, I. Enuschenko, (02-144e); 5,9: Buryatia Republic, Kiakhtinskii Raion, 7 km W of Kudara-Somon village, left bank of the Kudara River, 050¹0'07"N 107¹7'39"E, 22:07:2010, V. Chepinoga, (10-937i,10-937f); 8: Irkutsk Oblast', Tulunskii Raion, 2 km W of Uigat village, left bank of the Kirei River, $054^{\circ} 05^{\prime} \mathrm{N} 100^{\circ} 34^{\prime} \mathrm{E}, 30: 06: 2007$, V. Chepinoga, (07-678d): Holotypus ass: rel: 6.

For the abbreviations, see Table 1 . 
Caricetum pseudocuraicae ass. nova hoc loco Holotypus: rel. 5, Table 4

Syntaxonomic position: Phragmito-Magnocaricetea; Magnocaricetalia; Magnocaricion elatae

Diagnostic species: Calamagrostis purpurea, Carex appendiculata, C. atherodes, $C$.pseudocu$\underline{\text { raica }}$. Constant species: Carex appendiculata, $\underline{C}$. pseudocuraica. Dominant species: Carex pseudocuraica

Communities with dominance of Carex pseudocuraica.

Structure. C. pseudocuraica is usually well pronounced dominant in its species-poor (5-10 species) communities. Stands are medium sized (40-100 $\left.\mathrm{m}^{2}\right)$ with cover up to $100 \%$.

Ecology. Communities of $C$. pseudocuraica prefer shallow waters (up to $30 \mathrm{~cm}$ ) of mesotrophic floodplain lakes and after dry season can be found on bared bottoms with silty-peat substratum often covered with thatch.

Distribution. C. pseudocuraica is a boreal and meridional species with East Asian distribution. The western limit of its area hardly reaches the Ynisei River. In Baikal Siberia, C. pseudocuraica is a common species in Tranbaikalia and on coast of the Lake Baikal. In Cisbaikalia, this species occurs in south of the region (mainly, Cis-Sayan depression). The association was found both in the south of Cisbaikalia (Iya and Belaya river basins) and in Transbaikalia (Khilok, Ingoda and Onon river basins). In earlier publications communities of $C$. pseudocuraica were mentioned for the Selenga (GRANINA, 1981) and Verkhnaya Angara (GRANINA, 1992) deltas. As the unranked community ('Carex pseudocuraica-Gesellschaft') the same vegetation type is known from Japan (FUJIWARA, 1996).

The low species richness, structure and ecology of the Caricetum pseudocuraicae definitely indicate belonging to the class Phragmito-Magnocaricetea. In the same time, high constancy of Carex appendiculata, the diagnostic species of the class Calamagrostietea langsdorffii, marks relationships with wet meadow vegetation.

\section{Glycerietum spiculosae Savich 1967}

Type: SAVICH (1967: 330, rel. 25, Table 15): Glyceria spiculosa $\mathrm{cop}_{3}$, Menyanthes trifoliata sp, Scolochloa festucacea sp., Carex utriculata (=
C. rostrata) sol, Calamagrostis neglecta sol, Comarum palustre sol, lectotypus hoc loco

Synonyms: Glycerio spiculosae-Phragmitetum australis Akhtyamov 1987 [ICPN Art. 1]

Syntaxonomic position: Phragmito-Magnocaricetea; Magnocaricetalia; Magnocaricion elatae

Species-poor communities with dominance of Glyceria spiculosa.

In the publication about Posolskoye mire on the south-eastern coast of the Lake Baikal, N.M. Savich described the association Glycerietum spiculosae (SAVICH, 1967). The short description was accompanied by one relevé in Table 15, which is selected here as a lectotype. Because all necessary requirements of the ICPN (WEBER \& al., 2000) are fulfilled, the name Glycerietum spiculosae Savich 1967 should be considered as effectively and validly published.

The association is typical for margins of oxbows with clayey-sand, sandy and silty peat substratum. G. spiculosa is a boreal and temperate species with East Asian distribution. In Irkutsk Oblast', the species has its western limit of distribution. The association Glycerietum spiculosae was recorded both in Cisbaikalia (Iya, Oka, Belaya river basins) and Transbaikalia (Khilok, Ingoda, Onon river basins) regions, as well as from coast of the Lake Baikal.

Tephroseridetum palustris Mirkin \& al. 1985 nom. mut. prop.

Original form: (MIRKIN \& al., 1985): Senecionetum congesti $($ Senecio congestus $=$ Tephroseris palustris)

Synonym: Tephroseridetum palustris Burrichter ex Pott 1995

Syntaxonomic position: Bidentetea tripartitae, Bidentetalia tripartitae, Bidention tripartitae

Communities with dominance of Tephroseris palustris

Tephroseris palustris (L.) Rchb. (= Senecio palustris $(\mathrm{L}$.$) Hook., = S. congestus (\mathrm{R} . \mathrm{Br}$.) DC., = $S$. arcticus Rupr., $=S$. gracillimus $\mathrm{C}$. Winkl., $=S$. tubicaulis Mansf.) is a circumboreal polymorphic species with large distribution range (KoCHJAROVÁ, 2006). At present, most of taxonomists thought that the T. palustris complex is best trea- 
Table 4

Caricetum pseudocuraicae ass. nova

(Magnocaricion elatae, Magnocaricetalia, Phragmito-Magnocaricetea)

\begin{tabular}{lcccccccc}
\hline Area $\left(\mathrm{m}^{2}\right)$ & 40 & 100 & 20 & 100 & 80 & 48 & 100 & 100 \\
Cover herb layer $(\%)$ & 100 & 100 & 95 & 100 & 100 & 100 & 100 & 100 \\
Cover moss layer (\%) & 0 & 0 & 0 & 0 & 0 & 0 & 7 & 7 \\
Average depth (cm) & 0 & 25 & 0 & 0 & 25 & 30 & 10 & 5 \\
Soil char. & $\mathrm{sp}$ & $\mathrm{sp}$ & $\mathrm{sp}$ & $\mathrm{sp}$ & $\mathrm{sc}$ & $\mathrm{sp}$ & $\mathrm{sp}$ & $\mathrm{sp}$ \\
N. species & 5 & 5 & 6 & 6 & 6 & 6 & 10 & 10 \\
Relevé N. & 1 & 2 & 3 & 4 & 5 & 6 & 7 & 8 \\
\hline
\end{tabular}

\begin{tabular}{|c|c|c|c|c|c|c|c|c|}
\hline \multicolumn{9}{|c|}{ Characteristics of Caricetum pseudocuraicae (d.s.) } \\
\hline Carex pseudocuraica & 4 & 5 & 5 & 5 & 5 & 5 & 5 & 5 \\
\hline Carex appendiculata & . & . & 1 & + & 1 & 1 & 1 & + \\
\hline Carex atherodes & . & . & . & . & + & $\mathrm{r}$ & . & . \\
\hline Calamagrostis purpurea & . & . & . & . & + & 1 & . & . \\
\hline \multicolumn{9}{|l|}{ Characteristics of Lemnetea } \\
\hline Lemna turionifera & . & . & . & . & . & . & 1 & 1 \\
\hline Riccia fluitans (d) & . & . & . & . & . & . & + & + \\
\hline Spirodela polyrhiza & . & . & . & . & . & . & + & + \\
\hline Utricularia macrorrhiza & . & . & . & . & . & + & + & $\mathrm{r}$ \\
\hline \multicolumn{9}{|c|}{ Characteristics of Phragmito-Magnocaricetea (d.s.) } \\
\hline Acorus calamus & . & . & . & $\mathrm{r}$ & . & . & + & $\mathrm{r}$ \\
\hline Carex rostrata & . & $\mathrm{r}$ & + & + & . & . & . & . \\
\hline \multicolumn{9}{|l|}{ Other species } \\
\hline Brachythecium mildeanum (d) & . & · & $\cdot$ & . & . & . & $\mathrm{r}$ & $\mathrm{r}$ \\
\hline Drepanocladus aduncus $(\mathrm{d})$ & . & . & . & . & . & . & 2 & 1 \\
\hline Persicaria amphibia var. terrestre & $\mathrm{r}$ & + & . & . & . & . & . & . \\
\hline
\end{tabular}

Recorded in one relevé only: Cicuta virosa and Naumburgia thyrsiflora r, Menyanthes trifoliata 3 in 1; Carex lasiocarpa 1, Glyceria spiculosa 2 in 2; Equisetum fluviatile and Glyceria triflora $\mathrm{r}$, Carex vesicata 2 in 3; Bidens radiatus $\mathrm{r}$, Persicaria hydropiper 2 in 4; Salix miyabeana (b) and Scirpus radicans $\mathrm{r}$ in 5; Malus baccata (c) $\mathrm{r}$ in 6; Galium trifidum $\mathrm{r}$ in 7 ; Ricciocarpos natans $(\mathrm{d})+$ in 8 .

Localities. 1: Irkutsk Oblast', Cheremkhovskii Raion, Bazhei village, laklet within the sattlement, $52^{\circ} 58^{\prime} \mathrm{N} 102^{\circ} 39^{\prime} \mathrm{E}$, 02.08.2006, V. Chepinoga, (06-670b); 2: Irkutsk Oblast', Tulunskii Raion, 2 km N of Krasnoozerskii village, floodplain of the Iya river, oxbow Kubyshka, $54^{\circ} 17^{\prime} \mathrm{N} 100^{\circ} 42^{\prime} \mathrm{E}, 02.07 .2007$, V. Chepinoga, (07-689c); 3: Zabaikalskii Krai, Uletovskii Raion, $10 \mathrm{~km} \mathrm{SW}$ of the Tataurovo village, oxbow Podgornoe in floodplain of the Ingoda River, 51 $32^{\prime} 08^{\prime \prime} \mathrm{N} 112^{\circ} 49 ' 54 " \mathrm{E}, 12.08 .2007$, V. Chepinoga, (07-751n); 4: Zabaikalskii Krai, Uletovskii Raion, 4 km WNW of the Drovianaya town, oxbow Krivoe in floodplain of the Ingoda River, 51 ${ }^{\circ} 35^{\prime} 14 " \mathrm{~N} 112^{\circ} 59^{\prime} 28^{\prime \prime} \mathrm{E}, 12.08 .2007, \mathrm{~V}$. Chepinoga, (07-752k); 5,6: Zabaikalskii Krai, Ononskii Raion, west outskirts of the Chindant-1 village, oxbow Khlebnoe in floodplain of the Onon River, 50³3'00"N 115²1'07"E, 08.07.2008, V. Chepinoga, S. Rosbakh (08780j, 08-780k); 7,8: Buryatia Republic, Bichurskii Raion, 8 km NE of th Okino-Kluchi village, oxbow Ochirovo in floodplain of the Khilok River, $50^{\circ} 38^{\prime} \mathrm{N} 107^{\circ} 11^{\prime} \mathrm{E}, 08.07 .2006$, V. Chepinoga, (06-572f, 06-572h). Holotypus ass: rel: 5 .

For the abbreviations, see Table 1.

ted as a single, polymorphic species (e.g., BARKLEY \& MURRAY, 2006).

Communities with dominance of T.palustris are known in Europe under the name Tephroseridetum palustris Burrichter ex Pott 1995, but ten years earlier the same community type was validly described by Mirkin \& al. (1985) as Senecionetum congesti (type: Mirkin \& al., 1985: 389, tab. 18, rel. 23 (marked with "ó"): Tephroseris palustris (Senecio congestus) 5, Agrostis stolonifera $+)$. The nomen mutatum is proposed in accordance with ICPN Art. 45 because the name Tephroseris palustris is using instead of Senecio congestus $(=S$. palustris) in the most important taxonomic literature of the last 20 years (e.g., FLANN, 2009+). 
The association was described from alases in Central Yakutia, and included in the PhragmitoMagnocaricetea (Mikin \& al., 1985). In the same time, in European vegetation surveys communities of $T$. palustris together with other ruderal plant communities on wetland habitats are attributed to the Bidentetea tripartitae (Ротт, 1995; Mucina, 1997; Berg \& al., 2004). Stands of $T$. palustris from Yakutia (MIRKIN \& al., 1985) are extremely poor in species and don't contain other diagnostic species of the Bidentetea tripartitae. Nevertheless, taking into account that even in high latitudes $T$. palustris is more common in areas of intensive anthropogenic disturbance (KoROBKOV \& YURZEV, 1987, as Senecio congestus), it appears appropriate to classify the Tephroseridetum palustris in the Bidentetea tripartitae.

\section{ACKNOWLEDGEMENTS}

The study was supported by the Russian Foundation of Basic Research (14-04-00771-a) and by the Ministry of Education and Science of the Russian Federation (RNP. 2.2.3.1.4647).

\section{REFERENCES}

Anenkhonov, O.A. - 2003 - Syntaxonomy of the Alliance Caricion appendiculatae Akhtyamov \& al. 1985 (Calamagrostietea langsdorffii) in the Northern Trans-Baikal Area - Veg. Russia 5: 3-18. (In Russian with English abstract).

Azovsky, M.G. - 1981 - Higher aquatic vegetation in some glacial oligotrophic lakes in Northern Pribaikalie - In: Circulation of matter and energy in reservoirs. Proceedings of V. All-Soviet Limnological Conference. 1. Elements of the biotic circulation. Pp. 39-41. Irkutsk. (In Russian).

Azovsky, M.G. - 2000 - Higher aquatic vegetation in oligotrophic lakes of the catchment area of Lake Baikal In: Problems of ecology, biodiversity and protection of ecosystems of Pribaikalie. Pp. 6-15. Irkutsk St. Univ. Press, Irkutsk. (In Russian).

Barkley, T.M. \& Murray, D.F. - 2006- Tephroseris - In: Flora of North America Editorial Committee (Eds.). Flora of North America and north of Mexico. Vol. 20 Pp. 615-618. Oxford Univ. Press, New York.

Berg, C., Dengler, J., Abdank, A. \& Isermann, M. (Eds.) 2004- Die Pflanzengesellschaften Mecklenburg-Vorpommerns und ihre Gefährdung. Textband Weissdorn-Verlag, Jena. 606 pp.

Chepinoga, V.V. - 2009- Provisional subdivision of the Baikalian Siberia for characterization of vascular plant distribution - The Bulletin of Irkutsk State University. Series. - Biology and Ecology 2(2): 3-7. (In Russian with English abstract).

Chepinoga, V.V. - 2012 - Wetland vegetation database of Baikal Siberia (WETBS) - In: Dengler, J., Oldeland, J., Jansen, F., Chytrý, M., Ewald, J., Finckh, M., Glöckler, F., Lopez-gonzalez, G., Peet, R.K. \& Schaminée, J.H.J. (Eds.). Vegetation databases for the 21 st century. Biodiversity \& Ecology 4: 311.

Chepinoga, V.V. - 2013 - Flora and vegetation of water bodies and streams in south of the Eastern Siberia. Synopsis of the habilitation - Tomsk. 39 pp. (in Russian).
Chepinoga, V.V., Bergmeier, E., Rosbakh, S.A. \& Fleckenstein, K.M. - 2013 - Classification of aquatic vegetation (Potametea) in Baikal Siberia, Russia, and its diversity in a North Eurasian context - Phytocoenologia 43(12): $127-167$.

Chepinoga, V.V. \& Rosbakh, S.A. -2012- Aquatic vegetation (Lemnetea) in Baikal Siberia - Vegetation of Russia. 21: 106-123. (In Russian with English abstract).

Chepinoga, V.V., Stepantsova, N.V., Grebenjuk, A.V., Verkhozina, A.V., Vin'kovskaja O.P., Gnutikov, A.A., Dulepova, N.A., Enushchenko, I.V., Zarubin, A.M., Kazanovsky, S.G., Konovalov, A.S., Korobkov, A.A., Luferov, A.N. \& Rosbakh, S.A. - 2008- Check-list of the vascular flora of the Irkutsk region - Irkutsk St. Univ. Press, Irkutsk. 327 pp. (In Russian with English abstract).

Chytrý, M., Pešout, P. \& Anenchonov, O.A. - 1993Syntaxonomy of vegetation of Svjatoj Nos Peninsula, Lake Baikal. 1. Non-forest communities - Fol. Geobot. Phytotax. 28(3): 337-383.

Chytrý, M., Anenchonov, O.A. \& Danihelka, J. -1995Plant communities of the Bol'šoj Čivyrkuj River Valley, Barguzinskij Range, East Siberia - Phytocoenologia 25(3): 399-434.

Chytrý, M., Tichý, L., Holt, J. \& Botta-Dukát, Z. -2002Determination of diagnostic species with statistical fidelity measures - J. Veg. Sci. 13: 79-90.

De Molenaar, J.G. - 1976 - Vegetation of the Angmagssalik District, Southeast Greenland II. Herb and snow-bed vegetation - Meddelelser om Grønland 198: 1-266.

Dierschke, H. -1994- Pflanzensoziologie. Grundlagen und Methoden - E. Ulmer Verlag, Stuttgart. 684 pp.

Flann, C. (Ed.) - 2009- Global Compositae Checklist URL: http://compositae.landcareresearch.co.nz/Default. aspx. Accessed: 15.08.2014.

Fujiwara, K. -1996- Classification of plant communities in the Vegetation of Japan 1980-1989 - Bull. Inst. Env. Sci., Yokohama Natl. Univ. 22: 23-80. 
Granina, G.T. - 1981 - Research objects and classification of vegetation. - In: Galaziy, I.N. \& Beideman, I.N. (Eds.). Vegetation ecology of the Selenga River delta. Pp. 56-113. Nauka, Novosibirsk. (In Russian).

Granina, G.T. - 1992 - Geobotanical analysis of vegetation. - In: Galaziy, G.I. (Ed.). Vegetation of river ecosystems in the North Baikal. Pp. 10-87. Nauka, Novosibirsk. (In Russian).

Gregor, T. - 2003 - Eleocharis mamillata - distribution and infraspecific differentiation - Folia Geobot. 38: 49-64.

Ignatov, M.S., Afonina, O.M. \& Ignatova, E.A. - 2006Checklist of mosses of East Europe and North Asia Arctoa 15: 1-130.

Kaplan, Z. - 1995 - Genus Potamogeton on the Svjatoj Nos isthmus and in the Barguzinskaja valley, lake Baikal - Siberian Nat. Praha 1: 73-89.

Kochjarová J. -2006-Contribution to the occurrence and former distribution of Tephroseris palustris (Compositae) in the Central Europe - Biol. Bratislava 61(4): 361-364.

Kiprianova, L.M. \& Lashchinsky, N.N. -2000- New syntaxa of aquatic and coastal aquatic vegetation $-\mathrm{Si}$ berian J. Ecol. 2: 209-213. (In Russian with English abstract).

Konovalov, N.A. - 1930 - Issue of the vegetation in Selenga delta - In: Proceedings Commission of Lake Baikal investigation. 3. Pp. 159-192 - Leningrad. (In Russian).

Konstantinova, N.A. \& Bakalin, V.A. - 2009- Checklist of liverworts (Marchantiophyta) of Russia. - Arctoa 18: 1-64.

Korobkov, A.A. \& Yurzev, B.A. - 1987- Senecio L. In: Yurzev, B.A. (Ed.). Arctic flora of the USSR. Vol. 10. Rubiaceae-Compositae. Pp. 196-235. Leningrad, Nauka. (In Russian).

Koroljuk, A.Yu. - 2006 - Ecological optimum of South Siberia plant - Botanical investigations in Siberia and Kazakhstan. 12. Pp. 3-28. Irbis, Barnaul-Kemerovo. (In Russian).

Mirkin, B.M., Gogoleva, P.A. \& Kononov, K.E. - 1985The vegetation of Central Yacutian alases - Folia Geobot. Phytotax. Praha 20: 345-395.

Mucina, L. - 1997- Conspectus of classes of European vegetation - Folia Geobot. Phytotax. 32: 117-172.
Passarge, H. -1999- Pflanzengesellschaften Nordostdeutschlands. Band II: Helocyperosa und Caespitosa J. Cramer Verlag, Berlin. 451 pp.

Peshkova, G.A. - 1985 - Vegetation of Siberia. Cis-Baikalia and Trans-Baikalia - Nauka. Novosibirsk, 145 pp. (In Russian).

Pott, R. - 1995- Die Pflanzengesellschaften Deutschlands - E. Ulmer Verlag, Stuttgart. 622 pp.

Savich, N.M. - 1967 - Wetland near Posolsk - In: Tichomirov, B.A. (Ed.): Geobotanical investigations near Lake Baikal. Pp. 302-342. Nauka, Moskva. (In Russian).

Šumberová, K. - 2011- Vegetace vodních rostlin zakořeněných ve dně (Potametea) - Chytrý M. (Ed.). Vegetace České republiky. 3. Vodní a mokřadní vegetace. Pp. $102-$ 249. Academia, Praha. (In Czech).

Šumberová, K., Hájková, P., Chytrý, M., Hroudová, Z., Sádlo, J., M. Hájek, M., Hrivnák, R., Navrátilová, J., Hanáková, P., Ekrt, L. \& Ekrtová, E. -2011a- Vegetace rákosin a vysokých ostřic (Phragmito-Magno-Caricetea) - Chytrý M. (Ed.). Vegetace České republiky. 3. Vodní a mokřadní vegetace. Pp. 385-579. Academia, Praha. (In Czech)

Šumberová, K., Navrátilová, J., Čtvrtkíková, M., Hájek, M. \& Bauer, P. - 2011b - Vegetace oligotrofních vod (Littorelletea uniflorae) - In: Chytrý M. (Ed.). Vegetace České republiky. 3. Vodní a mokřadní vegetace. Pp. 268308. Academia, Praha. (In Czech).

Tichý, L. - 2002- JUICE, software for vegetation classification - J. Veg. Sci. 13: 451-453.

Weber, H.E., Moravec, J. \& Theurillat, J.P. -2000 - International Code of Phytosociological Nomenclature. 3rd edition - J. Veg. Sci. 11: 739-768.

Westhoff, V. \& van der Maarel, E. - 1973 - The BraunBlanquet approach - In: Whittaker, R.H. (Ed.). Ordination and classification of plant communities. Pp. 287-399. Dr. W. Junk Publ., The Hague.

Westhoff, V. \& van der Maarel, E. - 1978 - The BraunBlanquet approach - Whittaker R.H. (Ed.). Classification of plant communities. Pp. 289-399. Dr. W. Junk Publ., The Hague.

Zverev, A.A. - 2007 - Information technologies in studies of vegetation: tutorial - TML Press, Tomsk. 304 pp. (In Russian). 